\title{
WOŁANIE O REDAKTORA
}

\author{
HANNA BUCZYŃSKA-GAREWICZ, JAN GAREWICZ, \\ LISTY. WARSZAWA, PARYŻ, BOSTON
}

LESZEK KOŁAKOWSKI, ANDRZEJ WALICKI,

LISTY 1957-2007

KORESPONDENCJA JANA PATOČKI

Z IRENĄ KROŃSKĄ I KRZYSZTOFEM MICHALSKIM

[WRAZ Z LISTAMI TADEUSZA KROŃSKIEGO],

TŁUM. DANIEL R. SOBOTA, WOJCIECH STARZYŃSKI

Michał Rogalski

Warszawska Szkoła Historii Idei (dalej: WSHI) jest jednym z najważniejszych zjawisk w dwudziestowiecznej humanistyce polskiej. Jej losy nosza w sobie dramatyczne piętno wieku i przypominają nieco fabułę greckiej tragedii. Jej powstanie poprzedza krwawe ojcobójstwo popełnione na przedstawicielach Szkoły Lwowsko-Warszawskiej i innych reprezentantach przedwojennej profesury w imię proklamacji ideologii marksistowskiej, do czego inspiracją był list Bolesława Bieruta skierowany do uczestników I Kongresu Nauki Polskiej, niosący zachętę do osobowych i instytucjonalnych przetasowań oraz osobistych ataków filozoficznych, które podejmowali niektórzy późniejsi członkowie szkoły (zob. Kobiela 2011: 88-91). Równie dramatyczny był instytucjonalny koniec WSHI, związany z wy- 
darzeniami marca 1968 roku, kiedy to po okresie politycznych protestów w środowiskach akademickich doszło do czystek połączonych z bezpardonową nagonką antysemicką, która zmusiła do opuszczenia Polski tysiące jej obywateli. Filozoficzna działalność szkoły wydarzyła się pomiędzy tymi dwoma biegunami.

W latach 50. i 60. XX wieku w ramach Instytutu Filozofii i Socjologii Polskiej Akademii Nauk i Instytutu Filozofii Uniwersytetu Warszawskiego uformowało się w Warszawie środowisko intelektualne, do którego należeli m.in. Bronisław Baczko, Leszek Kołakowski, Irena Krońska, Tadeusz Kroński, Krzysztof Pomian, Adam Sikora, Barbara Skarga, Jerzy Szacki i Andrzej Walicki. Było to ważne środowisko nie tylko dla historii rewizjonistycznego marksizmu, ale przede wszystkim istotny nurt w dziejach polskich badań historyczno-filozoficznych i filozofii w ogóle. W ramach szkoły powstały istotne projekty edytorskie i badawcze, takie jak Biblioteka Klasyków Filozofii, Słownik Filozofów, Słownik Filozofów Polskich, edycja dzieł z filozofii polskiej, szereg prac badawczych nad myślą religijną okresu reformacji oraz myśla europejską i słowiańską w XIX wieku. Horyzonty zainteresowań członków szkoły były tak rozmaite i rozległe, że trudno znaleźć dla nich wspólny mianownik. Mogłaby nim być maskująca strategia myślenia i badań naukowych, w ramach której - dobierając tematy historyczne i pozornie dla marksistowskich sporów neutralne (jak reformacyjna myśl religijna, dzieje utopii czy rozwój słowianofilstwa) analizowało się dylematy filozoficzne o strukturze analogicznej do sporów toczonych w państwie autorytarnym, programowo socjalistycznym, gdzie wolność badań naukowych i naukowej wypowiedzi była znacząco ograniczona. Nie wszyscy przedstawiciele szkoły zgodziliby się jednak na taki opis i nie wszyscy się w niego wpisują. Można by także uznać, że powyższa differentia specifica kwestionuje uczciwość i wolność w doborze tematów badawczych i prowadzi do postawienia pod znakiem zapytania autentyczności wysiłku naukowego podejmowanego w badaniach historycznych, skoro miałyby mieć one charakter jedynie pretekstowy. O pretekstowości nie ma jednak w przypadku WSHI mowy, zbyt gruntowne bowiem i fundamentalne prace powstały w ramach badań prowadzonych przez jej członków ${ }^{1}$. Taka próba opisu może jedynie oferować punkt wyjścia, pierwsze defini-

\footnotetext{
${ }^{1}$ Można tu wskazać choćby: B. Baczko, Rousseau - samotność i wspólnota, Warszawa 1964; L. Kołakowski, Jednostka i nieskończonośc: wolnossć i antynomie wolności w filozofii Spinozy, Warszawa 1958; J. Szacki, Kontrrewolucyjne paradoksy: wizje swiata francuskich antagonistów Wielkiej Rewolucji 1789-1815, Warszawa 1965.
} 
cyjne przybliżenie i pomóc umiejscowić pozycję WSHI na mapie polskich badań filozoficznych w XX wieku.

Zadania dokumentacji i oceny tego dorobku podjęli się uczestnicy wieloletniego projektu grantowego „Warszawska szkoła historii idei i jej znaczenie w humanistyce polskiej" realizowanego przez IFiS PAN, który niegdyś stanowił instytucjonalne zaplecze szkoły. Jego efektem jest kilkanaście publikacji, których część składa się na serię wydawniczą „Archiwum Warszawskiej Szkoły Historii Idei. Źródła”. W ramach tejże serii opublikowano recenzowane w niniejszym tekście tomy korespondencji (recenzja dotyczy wszystkich zbiorów listów, które zostały w tym przedsięwzięciu wydane). Sa to trzy pozycje: (1) korespondencja Andrzeja Walickiego z Leszkiem Kołakowskim (2018), (2) korespondencja Ireny i Tadeusza Krońskich z Janem Patočka oraz korespondencja Krzysztofa Michalskiego z Janem Patočką (2018), a także (3) niekompletna korespondencja Hanny Buczyńskiej-Garewicz i Jana Garewicza wydana w dwóch tomach (2015).

Trzy zbiory korespondencji wydane w krótkiej serii - składającej się raptem z siedmiu pozycji (dla porównania: jej bliźniaczka - seria „Archiwum Warszawskiej Szkoły Historii Idei. Studia” liczy sobie jedenaście książek) - to zdecydowanie za mało, aby można mówić o przeglądowej choćby edycji dokumentów szkoły filozoficznej, do której należało co najmniej kilkanaście osób i składającej się przynajmniej z dwóch pokoleń. Kryteria wyboru - jeśli można o nich mówić w przypadku trzech pozycji - sa zbyt przypadkowe i niejasne jak na ambicje i plany deklarowane w opisach projektu badawczego. Strona redaktorska tych publikacji również pozostawia wiele do życzenia. Nie widać w nich ujednoliconych standardów edytorskich, a ich lektura rodzi wiele pytań co do jakości przygotowanego (lub właśnie wcale nieprzygotowanego!) aparatu krytycznego. Z uwagi na to, że w omawianej serii nie widać ani przemyślanego planu, ani ujednoliconych standardów wydawniczych (poza ujmującą, elegancką i jednolitą szatą graficzna), zajmę się każda pozycją z osobna i na koniec wyrażę kilka uwag na temat miejsca omawianych książek w całości projektu naukowego, którego są owocem.

\section{/// Tom wzorcowy i inicjatywa autorska}

Fundamentalne znaczenie dla dalszych badań nad WSHI ma wydany jako ostatnia pozycja w serii tom korespondencji Andrzeja Walickiego i Leszka Kołakowskiego, współtwórców szkoły i czołowych polskich historyków filozofii w XX wieku. Listy obejmuja kilka dekad (1957-2007) i stwarza- 
ją możliwość prześledzenia rozmowy, kluczowej dla zrozumienia losów przedstawicieli szkoły po 1968 roku (z roku 1957 pochodza jedynie dwa pierwsze listy z tomu, trzeci datowany jest już na 1968 rok). W korespondencji ścierają się dwie różne postawy polityczne, dwie strategie postępowania w warunkach ograniczonej wolności badań naukowych oraz dwie różne oceny własnego ideologicznego zaangażowania w marksizm.

Dla Kołakowskiego sprawa przestaje być zajmująca już po skończeniu trzytomowych Glównych nurtón marksižmu w 1978 roku. Uznał wówczas, że dał dostateczny wyraz swojemu krytycznemu i rozumiejącemu zarazem stosunkowi do myśli marksistowskiej, a w ten sposób odniósł się także do swojego w nią wkładu do 1968 roku. Walicki prowokuje go jednak wielorazowo do powrotu do dyskusji o tym, czy strategia kompromisu i uległości politycznej wobec partii rządzącej w latach 50. i 60. była usprawiedliwiona. Temat wraca przy kolejnych ważnych momentach w kształtowaniu się opozycji demokratycznej w Polsce: przy powstaniu KOR-u, w czasie karnawału Solidarności i później w latach 90. i na początku XXI wieku przy komentowaniu ówczesnego życia politycznego. Kołakowski każdorazowo sugeruje nieskuteczność i nieefektywność nawoływań Walickiego do ostrożności w działaniu i „nie wychylania głowy”.

Korespondencja jest też świadectwem niepewności własnego losu, emigracyjnych perypetii i dwóch wybitnych karier akademickich, które „umożliwił” rozpad warszawskiego środowiska filozoficznego na skutek represji pomarcowych. Tom wzbogacony jest o rozbudowany aneks, w którym mieszczą się: drobniejsze teksty obu autorów na tematy polityczne, teksty pisane o sobie nawzajem oraz niewielkie obrazki literackie Kołakowskiego, będące pisanymi dla żartu charakterystykami wybranych przedstawicieli WSHI.

Czytelnik dowiaduje się z noty wydawniczej zamieszczonej na początku książki, że publikacja „powstała z inicjatywy Andrzeja Walickiego, który zaproponował jej układ i omówił ją w 2015 roku z Tamarą Kołakowską" (Kołakowski, Walicki 2018: 7). Gdyby zatem nie ta inicjatywa jednego z autorów korespondencji, nie powstałby najważniejszy tom wydany w serii dokumentującej działalność szkoły. Należałoby jedynie zapytać: co z inicjatywą całego zespołu badawczego i komitetu redakcyjnego, który podjął się badań i dokumentacji dziedzictwa WSHI?

Sam tom nie przynosi odpowiedzi na te pytania. Jest za to najlepiej przygotowaną edytorsko pozycją z tu recenzowanych. To zasługa Andrzeja Walickiego, który napisał na potrzeby wydania ponad studwudziestostro- 
nicowy komentarz autorski, i Henryka Citki, kustosza Archiwum Zbigniewa Herberta w Zakładzie Rękopisów Biblioteki Narodowej, który opatrzył listy setkami przypisów, zawierających noty biograficzne, odniesienia bibliograficzne, fachowe komentarze edytorskie, opisy instytucji wzmiankowanych przez korespondentów i komentarze do zawartych w tekstach aluzji. Dzięki tej redaktorskiej pracy tom zawiera wszystko, co zawierać powinien, i odpowiada najlepszym standardom edycji korespondencji.

Ciekawym dokumentem, który stanowi poniekąd przedłużenie wieloletniej wymiany listów z Leszkiem Kołakowskim, jest obszerny komentarz Andrzeja Walickiego. Autor zdradza w nim liczne oznaki niewygasłego osobistego zaangażowania w spór i żywego stosunku do zagadnień politycznych dyskutowanych wcześniej w listach. Istotną część tekstu poświęca na ponowne wytłumaczenie własnych racji i uzasadnienie postawy zawodowej i społecznej w latach 60. XX wieku. Stara się jeszcze raz dowieść słuszności strategii zminimalizowanego oporu i budowania kompromisów, która miała - jego zdaniem - zmniejszyć skalę represji i zachować choćby minimalną wolność badań naukowych i szczątkowa swobodę wymiany poglądów, jaką udało się w przestrzeni badań historyczno-filozoficznych wypracować (tamże: 244-250, 256-260). Tłumaczy obszernie przesłanki, na których się w tym postępowaniu opierał, i wrażliwość, z której ono wychodziło. Jest to więc zaangażowany głos autora i cenny dokument wchodzący do pewnego stopnia w skład korespondencji, na który Kołakowski nie miał już szansy odpowiedzieć. W samej korespondencji widać zresztą, że ten spór przestaje go w pewnym momencie interesować i zaczyna zbywać zachęty Walickiego do jego kontynuowania (tamże: 87-88).

Skrupulatny i cenny faktograficznie esej Walickiego jest nie tylko komentarzem naukowym badacza dziedzictwa WSHI - bo taka rolę filozof od wielu lat również odgrywa - ale stanowi głos aktora zaangażowanego w działalność szkoły. Pozycja Walickiego jest więc podwójna i brak w niej dystansu zewnętrznego obserwatora. Zespół naukowy prowadzący badania nad WSHI zrezygnował zaś z prawa, a być może i obowiązku, naukowego komentarza do edytowanych i wydawanych w ramach projektu źródeł. W przypadku tego tomu trudno może czynić z tego zarzut, skoro inicjatywa publikacyjna nie wyszła od osób bezpośrednio związanych z projektem. Przy dwóch pozostałych tomach korespondencji komentarz naukowy też jednak ograniczono do budzącego wątpliwości minimum lub zrezygnowano $z$ niego zupełnie. 


\section{/// Zdawkowy komentarz i środkowoeuropejski kolonializm}

Bliski zachowania podstawowych standardów edytorskich jest zbiór korespondencji Ireny i Tadeusza Krońskich z Janem Patočką, wydanej wraz $z$ dodatkiem wymiany listów pomiędzy wspomnianym czeskim filozofem a Krzysztofem Michalskim. Niewątpliwa jest wartość samego materiału zebranego w tym tomie, którego najobszerniejszą część stanowi korespondencja Ireny Krońskiej z Patočką. Dzięki tej rozmowie czytelnik może z bliska przyjrzeć się sytuacji osób związanych z WSHI po rozpadzie szkoły w 1968 roku: zarówno samej autorki listów, jak i wspominanych przez nią postaci. Krońskiej również nie oszczędziły czystki i represje polityczne, które doprowadziły do końca warszawski etapu istnienia szkoły i rozproszyły jej najważniejszych przedstawicieli po świecie. Filozofka pisze o tym jednak niechętnie i jedynie zdawkowo informuje o odsunięciu od kierowania Biblioteką Klasyków Filozofii, której rozmach i wysoka jakość stanowiły w dużej mierze efekt jej mozolnej pracy i która do dziś stanowi najważniejszy zbiór źródłowych tekstów filozoficznych w języku polskim.

Wielka wartość tego zbioru listów to regularność ich wymiany, która sprawia, że stanowią one dokument życia intelektualistki odsuniętej na boczny tor życia filozoficznego. Źródłem dochodów stało się dla Krońskiej w tym okresie (1968-1974) czytanie i tłumaczenie literatury pięknej, ale wciąż starała się zachować żywy związek z rozwojem ówczesnej myśli filozoficznej i drążyła interesujące ją zagadnienia, próbowała na miarę swoich możliwości sprzyjać polsko-czeskiej wymianie intelektualnej i śledzić rozwój badań fenomenologicznych i nad fenomenologia. Znaczący wpływ na taki kształt jej poszukiwań miała jej międzywojenna edukacja filozoficzna zdobyta m.in. u Romana Ingardena.

Listy Krońskich i Patočki przygotował do wydania i przetłumaczył Wojciech Starzyński (za korespondencję Michalski-Patočka odpowiadał Daniel R. Sobota), który opatrzył całość dość obszernym wstępem. Jego tekst jest przede wszystkim przeglądem podstawowych wątków podejmowanych $\mathrm{w}$ obu korespondencjach z obszernymi wyjątkami z listów, które znajduja się w tomie. Choć nie można tego rodzaju wprowadzeniu odmówić użyteczności, to zdecydowanie brak tu rozleglejszego komentarza filozoficznego i historycznego. Informacje biograficzne o autorach zajmuja jedynie cztery z dwudziestu stron całości i ograniczają się do podania najważniejszych danych na temat korespondentów i to też w niezasadnie okrojonej formie, bo rozwój intelektualny Jana Patočki, na przykład, zreferowany został tylko do 1935 roku, a przecież większość korespondencji 
pochodzi z lat 1969-1973. Brak też krótkiego choćby wprowadzenia historycznego zaznaczającego rolę 1968 roku w biografiach polskiej filozofki i jej czeskiego korespondenta, a przecież istotny kontekst dla ich pisania stanowią zarówno wydarzenia marca 1968 w Polsce, jak i Praska Wiosna, wraz z finałem w postaci interwencji wojsk Układu Warszawskiego w Czechosłowacji, będącej reakcją na tamtejsze liberalizacyjne reformy ustrojowe. Jeszcze większe znaczenie dla zrozumienia nastroju i treści korespondencji ma następująca po 1968 czechosłowacka „normalizacja” - przywracanie zależności od ZSRR i rozszerzanie wpływu miejscowej partii komunistycznej na każdy właściwie aspekt życia codziennego - i zbliżone, choć mniej nasilone, represje mające miejsce w Polsce. Represje te dotknęły zarówno Krońska, jak i Patočkę, ale symetryczność ich losów można śledzić jedynie poprzez listy. Autor nie uznał za stosowne szerzej omówić tego kontekstu.

Niezwykle dotkliwy jest brak komentarza filozoficznego wobec licznie poruszanych w listach zagadnień związanych z badaniami Patočki nad filozofia czeską. Stanowią one przecież bardzo istotny wkład myśliciela w badania filozoficzne i slawistyczne w ogóle. Po pierwsze, Patočka brał udział $\mathrm{w}$ pracach edytorskich nad wydaniem zbiorowym dzieł siedemnastowiecznego reformatora religijnego, encyklopedysty i myśliciela Jana Amosa Komenskiego i w istotny sposób wpłynął na współczesną recepcję tej istotnej dla europejskiej myśli postaci ${ }^{2}$. Po drugie, status klasycznych posiadają badania Patočki nad czeskim odrodzeniem narodowym, a więc okresem formowania się czeskiej myśli narodowej i ruchu niepodległościowego, momentem powstania ujednoliconej literackiej czeszczyzny i czasem fundamentalnych dla nowożytnej samoświadomości czeskiej polemik lingwistycznych, literackich i filozoficznych (Macura 1995). Patočka jako pierwszy dowiódł $\mathrm{i}$ udokumentował wpływ Bernarda Bolzana na myśl czołowych przedstawicieli odrodzenia narodowego (przede wszystkim polityka i historyka, współtwórcy partii staroczechów, Františka Palackiego), pokazując tym samym, że od początku procesów narodowoodrodzeńczych konkurowały ze sobą dwie koncepcje tożsamości narodowej - koncepcja lingwisty Josefa Jungmanna uznająca kluczową dla czeskiej samoidentyfikacji rolę języka oraz właśnie bolzanowska koncepcja terytorialna, wedle której za Czechów należy uważać wszystkich tych, którzy zamieszkują historyczne terytorium Czech bez względu na używany język czy rodowód

\footnotetext{
${ }^{2}$ Jan Patočka opracowywał wstępy do wydań krytycznych dzieł Komenskiego. Jest też autorem dziesiątek artykułów jemu poświęconych, zob. J. Patočka, Aristoteles, jeho prédchridci a dédicové. Studie z déjin filosofie od Aristotela k. Hegelovi, Praha 1964; tenże, Die philosophie der Erziehung des J. A. Comenius, Paderborn 1971.
} 
etniczny (Patočka 1969). Oba te spojrzenia wyznaczyły horyzont problemów, z którym czeska myśl filozoficzna i polityczna zmaga się do dzisiaj. Z dylematem tym bezpośrednio związana jest idea czechosłowacka, status mniejszości narodowych w I Republice Czechosłowackiej (1918-1938) oraz wreszcie słynne dekrety prezydenta Edwarda Beneša, wypędzenie czeskich Niemców i związane z tym do dziś reperkusje polityczne.

O tym wszystkim nie ma jednak we wstępie wzmianki, a istotna część korespondencji pozostaje w związku z tym niejasna. Jest to również przejaw kolonializmu u polskich badaczy i edytorów, którzy sprawy niezwiązane bezpośrednio z kontekstem polskim uznają za drugorzędne i niegodne wyjaśniania, szczególnie jeśli dotyczą nie Europy Zachodniej, ale krajów Europy Środkowej i Wschodniej, wobec których polska refleksja przyjmuje często wyższościowy i pobłażliwy stosunek.

Podobna zdawkowość komentatora tyczy się także pozycji Patočki w europejskim ruchu fenomenologicznym. Solidne omówienie jego znaczenia i rozległych kontaktów rzuciłoby cenne światło na wielokrotnie podkreślane przez Krońską znaczenie korespondencji, w której uczestniczy. Pozwoliłoby to także wytłumaczyć, dlaczego o nowe fenomenologiczne pozycje Krońska prosi akurat Patočkę, dotkniętego licznymi represjami i zamkniętego w kraju ukaranym za próby liberalizacji komunizmu. Milczenie wobec istotnych kontekstów tej korespondencji ma miejsce nie tylko we wstępie, ale także w licznych przypisach do listów. W znakomitej większości są to odniesienia bibliograficzne do tekstów wspominanych przez korespondentów (tu także zdarzają się opuszczenia, jak choćby na s. 42, 59 i 80), nie ma za to żadnych not biograficznych i objaśnień dotyczących kontekstów społecznych i politycznych, w których oboje autorów funkcjonowało. Brak choćby skrótowych informacji biograficznych świadczy także o bolesnej niekonsekwencji w ramach serii, bo w pozostałych pozycjach znajdują się one w lepszej (przypisy do korespondencji Walicki-Kołakowski) lub gorszej formie (korespondencja Garewiczów i szczątkowe informacje w indeksie osób).

\section{/// Brak komentarza i rezygnacja $\mathrm{z}$ aparatu}

Najwięcej do życzenia pozostawia jednak wydanie pierwszego ze zbiorów korespondencji opublikowanych w ramach serii - dwutomowa edycja listów Hanny Buczyńskiej-Garewicz i Jana Garewicza z lat 1960-1994. Oboje zaliczaja się do drugiego pokolenia szkoły - Jan Garewicz jako uczeń i student Tadeusza Krońskiego i Bronisława Baczki, ten ostatni był także 
promotorem jego pracy doktorskiej o Schopenhauerze; Hanna Buczyńska-Garewicz jako doktorantka Adama Sikory. Oboje autorów korespondencji łączyły również z pozostałymi twórcami szkoły liczne więzi zawodowe i towarzyskie.

Krótkie teksty edytorskie zamieszczone w tomie kilkukrotnie zapewniają czytelnika, że korespondencja miałaby być „znakomitym dokumentem czasów” i „świetną ilustracją” związków pomiędzy nauką a polityką i życiem społecznym, ale w istocie trudno ja za takie uznać. Choć w samym materiale niewatpliwie kryje się bardzo ciekawy potencjal dokumentacyjny, to w takiej postaci, w jakiej został wydany, dla znakomitej większości czytelników posiada on minimalną wartość. Nie odniesie się z czytania pożytku, jeśli nie wykona się wysiłku dodatkowych badań i uzupełnień, który powinien zostać podjęty przez zespół pracujący nad wydaniem korespondencji.

Podejrzeń co do tego, że coś jest z tym wydaniem nie tak, można nabrać już na samym początku książki, czytając kuriozalną notę od wydawcy. Informuje ona nie tylko o tym, że listy zebrane w dwutomowej edycji były dotąd niepublikowane, ale także, że: „Zgodnie z wolą Hanny Buczyńskiej-Garewicz tekstu listów nie opatrzono dodatkowymi informacjami, tak zwanym aparatem, dociekliwości Czytelnika pozostawiając ujawnienie tego, co kryje się za skrótami, aluzjami czy niedomówieniami” (Buczyńska-Garewicz, Garewicz 2015 I: 9). Wolę autorki należy oczywiście szanować, ale rodzi to pytanie, czy wydawcy serii w ogóle powinni się decydować na publikację takiego nieobrobionego, a więc z punktu widzenia badań naukowych niewiele wartego, materiału. Jeśli jego publikacja jest adresowana do badaczy specjalistów, to ci więcej pożytku odniosą, sięgając po maszynopisy listów - tym bardziej, że na podstawie nielicznych fotokopii zamieszczonych w publikacji można zauważyć, że edytorzy nie spisywali z listów wszystkiego, pomijali poprawki, nie sugerowali miejsc skreśleń, postępując w wielu przypadkach wbrew tradycjom rzetelnej pracy edytorskiej. Jeśli zaś publikacja ta ma służyć szerszemu gronu czytelników, to pozostawianie ich „dociekliwości” tego, co powinno być żelazną podstawą edycji krytycznej, a więc: przypisów, biogramów, rozwinięcia skrótów, koniecznego dla zrozumienia kontekstu politycznego i społecznego, jest decyzją nierozsądną. Projekt naukowy i publikacyjny z takimi ambicjami jak Archiwum Warszawskiej Szkoły Historii Idei nie powinien polegać na przepisywaniu odręcznie pisanych listów na komputerze.

Czytanie tego gołego i nieobrobionego materiału jest męczące i przynosi satysfakcję jedynie $\mathrm{z}$ rzadka. Listy bowiem są nie szkicami filozo- 
ficznymi, ale rozmową dwojga bliskich sobie osób. Trudno wymagać od czytelników, żeby sami wertowali encyklopedie, aby ustalić detale z życia politycznego globu, bloku wschodniego i wreszcie Polskiej Rzeczpospolitej Ludowej w kolejnych dziesięcioleciach XX wieku.

Niezrozumiałe są dla mnie również decyzje o niepublikowaniu części listów będących immanentną częścią tego korpusu tekstów. W wielu miejscach - jak choćby przy korespondencji z roku 1960 (tamże: 45, 48, 69) widać, że brakuje listów drugiej strony, do których odniesienia pojawiają się w listach publikowanych. Uzasadnienia dla takich decyzji oraz informacji o tym, ile listów i nieobecnych zupełnie kart pocztowych zostało pominiętych, próżno szukać w nocie od wydawcy, przedmowie czy wstępach do poszczególnych bloków korespondencji. Nie ma tej informacji również w przypisach - bo tych nie ma wcale.

Szczątkowy aparat krytyczny, który w tym wydaniu się znalazł, również jest niekompletny. Zamieszczony na początku indeks osób nie zawiera wszystkich bohaterów pojawiających się w korespondencji, nie rozwija ich pseudonimów, a nawet nie podaje wszystkich pseudonimów osób zawartych w indeksie. Łatwo to sprawdzić, porównując podane w nim informacje $z$ indeksem nazwisk, zamieszczonym na końcu drugiego tomu. Ten ostatni stanowi zresztą jedyne, skape źródło informacji biograficznych o osobach wymienianych w listach.

Trudno uznać ten dwutomowy zbiór listów za edycję naukową czy krytyczna. Jest to wysoce niepełne i wspominkowe wydanie, na które nie powinno pozwolić sobie wydawnictwo czołowej instytucji naukowej wchodzącej w skład Polskiej Akademii Nauk. Nie ma tu aparatu krytycznego, nie ma osobnego edytora, związanego bezpośrednio z projektem grantowym, który umoźliwił wydanie, nie ma też - poza przedmową samej autorki listów, Hanny Buczyńskiej-Garewicz - żadnego krytycznego wstępu ani posłowia do całości. Nie ma nic z tego, co powinno się tu znaleźć. To czyni te tomy najsłabsza pozycją z całej serii i nie ma to żadnego związku z samą treścią tych listów.

Dość jednak o jakości wydania. Należy tu bowiem jeszcze postawić pytanie, czy sama decyzja o wydaniu tej korespondencji w serii była dostatecznie uzasadniona. Niewątpliwie oboje korespondentów można zaliczyć do WSHI, ale raczej do pierwszego pokolenia uczniów (drugiego pokolenia szkoły) niż do pokolenia założycieli. Czy od nich powinno się zaczynać badanie dziedzictwa WSHI? Pewnym argumentem mogłaby być istotna rola Jana Garewicza w powołanym przez członków szkoły czasopiśmie „Archiwum Historii i Myśli Społecznej” - był wieloletnim sekretarzem redakcji 
i brał udział w jej pracach od pierwszego numeru. Ale czy publikacja tych listów przynosi naukową korzyść przy tak restrykcyjnych wymaganiach autorki i dysponentki praw do listów, aby nie tworzyć żadnego aparatu krytycznego? Autorka ma oczywiście do tego pełne prawo i jej żądanie nie może stanowić podstawy do żadnych zarzutów. Czy edytorzy jednak nie powinni w takiej sytuacji wybrać innych z niezwykle licznych materiałów stworzonych przez członków szkoły, a tę publikację odłożyć na półkę do czasu, gdy wyczerpująca i wartościowa analiza korespondencji stanie się możliwa?

\section{/// Badawcze zaplecze a recenzowana korespondencja}

Moje wątpliwości dotyczące standardów wydania tomów korespondencji WSHI i szerszego konceptu, stojącego za przyjętym planem wydawniczym, rozszerzają się na całość projektu naukowego o tytule „Warszawska szkoła historii idei i jej znaczenie w humanistyce polskiej", finansowanego z Narodowego Programu Rozwoju Humanistyki w kwocie 1000000 złotych i realizowanego w latach 2012-2018. Decyduję się na opisanie tych zastrzeżeń w recenzji publikacji książkowych, ponieważ zarówno znaczenie badanego tematu, jak i fakt otrzymania publicznego finansowania czynia z niego przedmiot, który może być poddany publicznej dyskusji w środowisku naukowym. A analiza strategii edytorskiej projektu i jej wyników nasuwa w mojej opinii wiele wattpliwości. Nie stawiam się tu bynajmniej na pozycji recenzenta projektu grantowego, uważam jedynie, że skoro wyniki sześcioletniej pracy naukowej są istotną częścią akademickich badań filozoficznych w Polsce, to trzeba zastanowić się nad ich jakością i nad tym, jak niezwykle cenne dziedzictwo intelektualne zostało potraktowane przez badaczy z czołowej polskiej jednostki badawczej.

Wszystkie prace podejmowane $\mathrm{w}$ projekcie zostały zebrane i opisane na specjalnym portalu internetowym, dostępnym pod adresem: http://www.archidei.ifispan.pl/ (dostęp: 21.04.2020). Pomimo specjalnej zakładki „O szkole” na portalu nie ma żadnej definicji tego, czym była Warszawska Szkoła Historii Idei. Tekst zatytułowany „Historia i wprowadzenie" jest pobieżnym utyskiwaniem na to, że ciagłość wpływu tej szkoły została zerwana, wyszczególnieniem kilku przyczyn owego zerwania i wezwaniem do powrotu do tego dziedzictwa myślowego. Próżno jednak szukać informacji, kto do szkoły należał (biogramy zamieszczone obok nie rozwiewaja tu wattpliwości, bo nie ma wśród osób opisanych choćby Ireny Krońskiej), jak powstała, w jakim kontekście polityczno-społecz- 
nym się formowała, jakie były jej prace, co można uznać za jej koniec, jakie pokolenia da się tu wyróżnić i jak scharakteryzować jej dotychczasowy wpływ na polską myśl filozoficzna. Główne narzędzie do popularyzacji i prezentacji dorobku WSHI nie daje więc żadnej możliwości, aby czytelnik, który nie przyswoił sobie choćby w podstawowym zarysie wiedzy o tym, z czym ma w przypadku WSHI do czynienia, taką wiedzę zdobył.

W zakładce „O szkole” znajdują się oczywiście - jak głosi szumnie tytuł - „Biogramy i bibliografie” członków szkoły, ale długościa przypominają raczej pobieżne notki w encyklopedii. Nie prezentują żadnych wzajemnych związków pomiędzy postaciami, nie rozwijają kluczowego zagadnienia związków danej osoby z WSHI. Bibliografie prac nie są zaś de facto żadnymi bibliografiami, ale wymienieniem kilku najważniejszych polskojęzycznych prac autora z podaniem w nawiasie daty pierwszego wydania.

Jak głosi zamieszczony na stronie opis projektu, jego głównym celem naukowym było „opracowanie zespołu archiwalnego, dokumentacja i edycja dorobku Warszawskiej Szkoły Historii Idei, a także upowszechnienie wyników badań nad jej znaczeniem w humanistyce polskiej na tle humanistyki europejskiej". Już samo przejrzenie strony stanowiącej dokumentacje projektu każe zadać pytanie, czy cel ten został w zadowalający sposób osiągnięty.

Opisywany projekt przyniósł efekty w postaci publikacji książkowych w serii „Archiwum Warszawskiej Szkoły Historii Idei” podzielonej na dwie podserie „Źródła” i „Studia”. W serii „Źródła” ukazywały się „pomnikowe dzieła przedstawicieli Warszawskiej Szkoły Historii Idei oraz dokumenty i świadectwa, prezentujące jej dorobek i historię". Jeżeli chodzi o ,pomnikowe dzieła” w ramach projektu opublikowano wznowienie po jednej pracy Bronisława Baczki, Tadeusza Krońskiego i Jerzego Szackiego. Jeżeli zestawić te trzy pozycje z 24 biogramami osób opisanych jako przedstawiciele WSHI, to ilość publikacji „pomnikowych dzieł” okazuje się nad wyraz skromna. Owszem, prace Leszka Kołakowskiego, Barbary Skargi, Bronisława Baczki i Andrzeja Walickiego są wznawiane i obecne w obiegu intelektualnym, ale spośród tego grona jedynie prace Barbary Skargi doczekały się edycji zebranej. W przypadku pozostałych autorów dałoby się z pewnością odnaleźć w ich dorobku dzieła ważne, a nigdy nie wznawiane bądź pozostałe w rękopisie. Jednak nawet uznając za usprawiedliwione pominięcie w edycji najważniejszych przedstawicieli szkoły, wciąż pozostaje znacząca liczba jej członków zupełnie nieuwzględnionych w publikacyjnych planach serii. 
Można by to oczywiście zrzucić na karb skomplikowanych kwestii majątkowego prawa autorskiego, które wciąż wiąże się z publikacja prac wszystkich członków szkoły, ale czyż nie po to występuje się o wsparcie grantowe dla projektu, żeby nie musieć przejmować się obecnością lub nieobecnością autora w domenie publicznej? Nie finanse są tu jednak kluczowe, choć oczywiście nie bagatelizowałbym pytania o to, jakiej jakości należy oczekiwać po flagowych projektach humanistyki polskiej finansowanych z pieniędzy publicznych. Najistotniejszy jest wyraźny brak planu i spójnej koncepcji myślenia o dziedzictwie WSHI, który widać w omawianym projekcie na każdym kroku. Brak tu jasnych definicji, precyzyjnych narzędzi do analizy i wyraźnego planu publikacyjnego. Panuje raczej bałagan i działanie doraźne, które prowadzą do tego, że w jednej szacie graficznej wydaje się rzeczy zestawione ze sobą przypadkową metodą „co się uda”: czyjąś zapomnianą nieco pracę, monografie luźno inspirowane ideami szkoły, zbiory artykułów z konferencji, jedną rozbudowaną bibliografię i kalendarium, które udało się opracować, oraz kilka tomów korespondencji ${ }^{3}$.

Kontynuacji prac trudno by się spodziewać, bazując na zamieszczonych na portalu informacjach na temat tego zakończonego projektu. $\mathrm{Na}$ początku 2020 roku ukazal się jednak drugi numer czasopisma „The Interlocutor. Journal of the Warsaw School of the History of Ideas" za lata 2018 i 2019. Czasopismo również stanowi jeden z efektów badań grantowych i choć wciąż nie posiada anglojęzycznej wersji swojej strony (zob. http://www.theinterlocutor.ifispan.pl/, dostęp: 20.05.2020) - co dość osobliwe jak na czasopismo wydawane w języku angielskim i skierowane do społeczności międzynarodowej - to jego tlące się życie jest promykiem nadziei na przyszłość.

Bibliografia:

/// Buczyńska-Garewicz H., Garewicz J. 2015. Listy. Warszawa, Paryż, Boston, t. I-II, IFiS PAN.

/// Kobiela F. 2011. „Tygrys” contra „Mefisto”. O ataku Krońskiego na Ingardena po 60. latach, „Kwartalnik Filozoficzny”, nr 4/2011, s. 88-91.

/// Kołakowski L., Walicki A. 2018. Listy 1957-2007, IFiS PAN.

\footnotetext{
${ }^{3}$ Jedynym systematycznie przeprowadzonym działaniem jest digitalizacja archiwalnych numerów czasopisma „Archiwum Historii Filozofii i Myśli Społecznej”. Stanowi ona powód do radości, choć powinna być raczej efektem ubocznym pracy dokumentacyjnej i interpretacyjnej.
} 
//I Korespondencja Jana Patočki z Irena Krońska i Krzysztofem Michalskim (wraz, z listami Tadeusza Krońskiego). 2018, tłum. D.R. Sobota, W. Starzyński, IFiS PAN.

/// Macura V. 1995. Znameni zrodu: české národni obrozeni jako kulturni typ, $\mathrm{H} \& \mathrm{H}$.

/// Patočka J. 1969. Dilema v našem národním programu - Jungmann a Bolzano, [w:] tegoż, O smysl dneškea. Devèt kapitol o problémech svètových i českých, Mladá fronta, s. 87-104.

/// Michał Rogalski - filozof, tłumacz, dramatopisarz i reżyser teatralny. Jest autorem książki Producenci margaryny? Marian Zdriechonski i polski modernižm katolicki (Kraków: Universitas 2018) poświęconej reformatorskim nurtom myślowym w polskim katolicyzmie na przełomie XIX i XX wieku. Jego zainteresowania badawcze obejmują historię myśli katolickiej w późnej nowożytności oraz filozoficzne aspekty światopoglądów religijnych.

ORCID: https://orcid.org/0000-0001-8225-7026

E-mail: michal.f.rogalski@gmail.com 